\title{
The diagnostic efficacy of computed tomography in detecting diaphragmatic injury secondary to thoracoabdominal penetrating traumas: a comparison with diagnostic laparoscopy
}

\author{
Mehmet İlhan, M.D., ${ }^{1}$ Mesut Bulakçı, M.D., ${ }^{2}$ Süleyman Bademler, M.D., ${ }^{1}$ Ali Fuat Kaan Gök, M.D., ${ }^{1}$ \\ İbrahim Fethi Azamat, M.D., ${ }^{1}$ Cemalettin Ertekin, M.D. ${ }^{1}$
}

${ }^{1}$ Department of General Surgery, Trauma and Emergency Surgery Service, İstanbul University İstanbul Faculty of Medicine, İstanbul ${ }^{2}$ Department of Radiology, İstanbul University İstanbul Faculty of Medicine, İstanbul

\begin{abstract}
BACKGROUND: This study was designed to investigate the diagnostic efficacy of computed tomography (CT) for the detection diaphragmatic injury in cases undergoing diagnostic and therapeutic laparoscopy in left thoracoabdominal penetrating injuries.

METHODS: Demographic properties, stabbed body region, additional injuries, hemodynamic parameters, time to admission, diagnostic examinations, and type of treatment were retrospectively reviewed in one hundred and eight patients presenting with left thoracoabdominal injury after penetrating sharp object injury between April 2010 and December 20I4. Preoperative CT scans of all patients were reviewed blind to the results of surgical evaluation. The relationship between diaphragmatic injury and hemothorax, pneumothorax, abdominal free fluid, and solid organ injuries were analyzed. All patients underwent physical examination, complete blood count monitoring, and hemodynamic assessment prior to surgery.
\end{abstract}

RESULTS: The most common finding on physical examination was anterior left thoracoabdominal injury. The injury was detected surgically in $36 \%$ of twenty-five cases with lateral injury. Diaphragmatic injury was present in twenty-five (23.1\%) of all cases, all of whom were treated with laparoscopic repair. An analysis of all CT findings in relation to surgical results revealed that CT had a sensitivity of $80 \%$, a specificity of $95 \%$, a PPV of $83 \%$, and a NPV of $94 \%$ for the detection of diaphragmatic injuries. Mean duration of hospital stay was 5.4 days (range, $1-16$ days) in the entire study population.

CONCLUSION: CT is still associated with diagnostic challenges in penetrating diaphragmatic injuries. Nevertheless, CT showed a high specificity and a negative predictive value in our study. Detection of a diaphragmatic defect and fatty tissue herniation makes the definitive diagnosis of diaphragmatic injury in penetrating thoracoabdominal injuries. Prospective studies with a larger sample size are necessary to further clarify the role of CT in detection of diaphragmatic injuries in thoracoabdominal sharp penetrating object injuries.

Key words: Diaphragmatic injury; laparoscopy; MDCT; penetrating trauma; thoracoabdominal.

\section{INTRODUCTION}

Diaphragmatic injuries may occur via blunt or penetrating trauma. Penetrating traumas are caused by firearm injuries

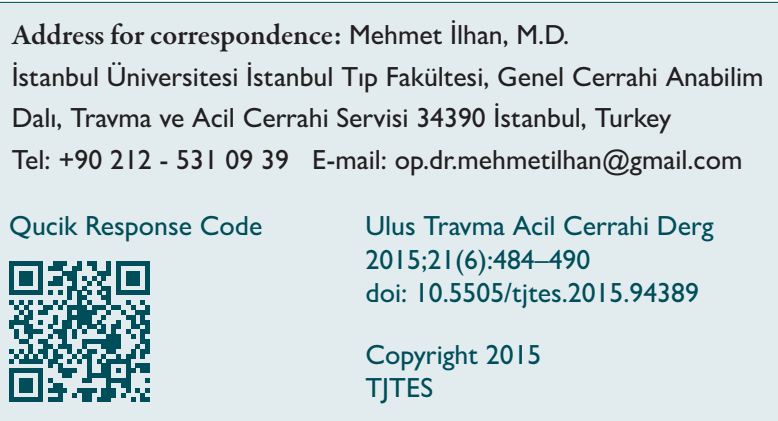

or sharp penetrating object or stabbing injuries, which can be easily overlooked. It is difficult to make the diagnosis when specific symptoms and radiological signs are absent. Sometimes, laparotomy operations performed years after sharp penetrating object injuries may incidentally detect diaphragmatic hernias. ${ }^{[1]}$

Isolated penetrating diaphragmatic injuries rarely causes clinically overt symptoms and prominent radiological signs because they usually give rise to small diaphragmatic tears with a size of only I to $4 \mathrm{~cm}$. In cases managed conservatively, missed diaphragmatic injuries may lead to serious diaphragmatic hernias and associated life-threatening complications over time. Mortality rates of visceral herniation and strangulation reportedly range between $30 \%$ and $60 \%$. Various 
imaging studies including chest X-Ray, ultrasonography, CT, and $\mathrm{MRI}$ are used to diagnose diaphragmatic injuries. In emergency departments; however, CT is regarded as the imaging test of choice owing to its ability to rapidly detect even small defects with the help of multiplanar reconstruction images. ${ }^{[2,3]}$

There are only a few studies that have specifically focused on diaphragmatic injuries caused by sharp penetrating objects. This study, by retrospectively reviewing MDCT scans, aimed to determine the diagnostic efficacy of multidetector computed tomography (MDCT) for diaphragmatic injuries in patients presenting with left thoracoabdominal penetrating sharp object injury in which diaphragmatic injury was evaluated by laparoscopy. The presence of a diaphragmatic defect, other organ injuries accompanying diaphragmatic injury, and some CT signs specific to diaphragmatic injuries previously described in the literature were sought for.

\section{MATERIALS AND METHODS}

The ethics committee of our hospital approved this retrospective case-control study and waived the requirement for informed patient consent.

\section{Patients}

This study retrospectively reviewed the medical records of one undred and eight patients who had a left thoracoabdominal sharp penetrating object injury and underwent a CT among patients presenting to the Trauma and Emergency Surgery Unit with penetrating trauma between April 2010 and December 2014. Right thoracoabdominal injuries (not surgically intervened), hemodynamic instability, urgent surgery for accompanying injuries, and patient refusal of surgery, who have left thoracoabdominal injuries were the exclusion criteria. Patients presenting to our hospital were examined according to the advanced trauma life support protocol. ${ }^{[4]}$ All patients were applied tetanus prophylaxis. The patients were grouped into three groups based on the injured body region:

I. Anterior left thoracoabdominal injury: Injuries located anterior to the axillary line (below the nipple in front, left superior quadrant of the abdomen).

2. Lateral left thoracoabdominal injury: Left thoracoabdominal injuries between the anterior axillary line and the posterior axillary line (below the sixth intercostal space, left superior quadrant of the abdomen).

3. Posterior left thoracoabdominal injury: Injuries located posterior to the posterior axillary line (the eighth intercostal space at the back, left superior quadrant of the abdomen).

All skin incisions were primarily sutured after the first examination. Patients without symptoms, hemodynamical instability, or a need for urgent surgery for accompanying injuries were admitted to hospital. After a mean of 48 hours of monitoring, patients were evaluated for diaphragmatic injury. Patients with intraabdominal solid organ injury were operated on between fourth and fifth days, and six of them were applied thoracoscopy.

\section{Evaluation Methods and Diagnostic Techniques}

- Physical examination - leucocyte counting: Patients with a high likelihood of simultaneous intraabdominal organ injury were followed with close monitoring and serial physical examinations. After hospital admission, leukocyte counting and serial physical examinations were performed at every four hours.

- Diagnostic laparoscopy: It was applied in lower thoracic injuries to exclude the possibility of diaphragmatic injury when laparotomy was not indicated.

- Diagnostic thoracoscopy: It was applied in lower thoracic and splenic injuries to exclude the possibility of diaphragmatic injury when laparotomy was not indicated.

- Diagnostic single-port laparoscopy: It was applied in left thoracoabdominal injuries as an alternative to diagnostic laparoscopy to exclude the possibility of diaphragmatic injury

- Imaging studies: Chest X-Ray, Abdominal Ultrasound (FAST), MDCT

- MDCT protocol: Admission thoracoabdominal MDCT was performed on a 16 (Brilliance 16; Philips Medical Systems, Eindhoven, Netherlands) or 64 (Aquilion 64; Toshiba Medical Systems, Otawara-shi, Japan) slice CT system. As the CT device used for imaging of the study subjects was replaced by a new one during the study period, the imaging studies were done with two different devices. Body regions from the level of thoracic inlet to symphysis pubis were scanned. Oral and IV contrast materials were routinely administered unless there were contraindications. A uniphasic injection of $100-120 \mathrm{ml}$ of contrast agent at a rate of $2-3 \mathrm{ml} / \mathrm{s}$ was given to the patients, and images were obtained $60-70 \mathrm{~s}$ after the start of intravenous contrast medium administration.

- Image interpretation: The images of the patients were stored in our hospital's picture archiving and communication system (PACS), and they were retrospectively reviewed in thin sections on axial, coronal, and sagittal planes (ExtremePACS,Ankara,Turkey). All CT images were reviewed blind to the surgical results. CT scans of the patients were reviewed and classified into two categories; positive ([+]; injury was detected), negative ([-]; no injury was detected). The study was considered positive when the defect was directly visualized, when herniation of an intraabdominal organ or fatty tissue was observed, or when contiguous injuries extending to both sides of diaphragm along the injury tract were present. Additionally, each patient was also evaluated for the signs accompanying diaphragmatic injury including pericardial effusion, hemothorax, pneumothorax, lung parenchymal injury, rib fracture, hepatic, splenic, or pancreatic injury, 
Table I. The region of injury and CT findings according to the findings on physical examination, LTI, SDI

\begin{tabular}{|c|c|c|c|c|c|c|}
\hline & $\begin{array}{c}\text { Anterior } \\
\text { LTI }\end{array}$ & $\begin{array}{c}\text { Lateral } \\
\text { LTI }\end{array}$ & $\begin{array}{c}\text { Posterior } \\
\text { LTI }\end{array}$ & $\begin{array}{c}\text { Anterior lateral } \\
\text { LTI }\end{array}$ & $\begin{array}{c}\text { Anterior- } \\
\text { posterior LTI }\end{array}$ & $\begin{array}{c}\text { Posterolateral } \\
\text { LTI }\end{array}$ \\
\hline Number of patients & 50 & 25 & 22 & 6 & 2 & 3 \\
\hline Number of patients detected to have a SDI & 10 & 9 & 3 & 2 & - & I \\
\hline Diaphragmatic injury on CT & 9 & 6 & 3 & I & 1 & - \\
\hline Pneumothorax & 24 & II & II & 2 & I & 2 \\
\hline Haemothorax & 27 & 14 & 11 & 2 & I & 2 \\
\hline Solid organ injury & 3 & 6 & 2 & I & 2 & - \\
\hline
\end{tabular}

CT: Computed tomography; LTI: Left thoracoabdominal injury; SDI: Surgical diaphragmatic injury.

gastric or intestinal injury, intra or retroperitoneal free air, intra or retroperitoneal hematoma, subcutaneous emphysema, and intraluminal or intravascular contrast extravasation.

\section{Statistical Analyses}

Demographic properties, trauma localization, laboratory results, physical examination findings, diagnostic study results, treatment plans, and complications were recorded on a database. The sensitivity, specificity, positive predictive value (PPV) and negative predictive value (NPV) levels of CT for detection of diaphragmatic injuries were compared with those of laparoscopy that is considered the reference method. The relationship between diaphragmatic injuries and other associated signs was explored using the Chi-square test. All statistical analyses were performed using the SPSS 21.0 statistical package (SPSS, Inc., Chicago, IL, USA). A p value of $<0.05$ was considered statistically significant.

\section{RESULTS}

One hundred and two patients were male, 6 of them were female. Mean age of the study population was 29 years (range, $|2-6|$ years). Twenty-three of the 95 cases undergoing diagnostic laparoscopy had diaphragmatic injury that was laparoscopically repaired. One of the 7 cases undergoing single-port diagnostic laparoscopy was detected to have a diaphragmatic injury that was primarily repaired (Fig. Ia-c). Of the 6 patients undergoing diagnostic thoracoscopy, one had diaphragmatic injury that was repaired with thoracoscopy. The most common physical examination findings were anterior and lateral injuries (Fig. Id, e). Mean duration of hospital stay was 5.4 days (range, I-16 days). No significant correlation was found between injury region and the presence of a diaphragmatic injury. The injury regions and CT findings were presented in Table I.

CT scans revealed intraabdominal solid organ injury in four-
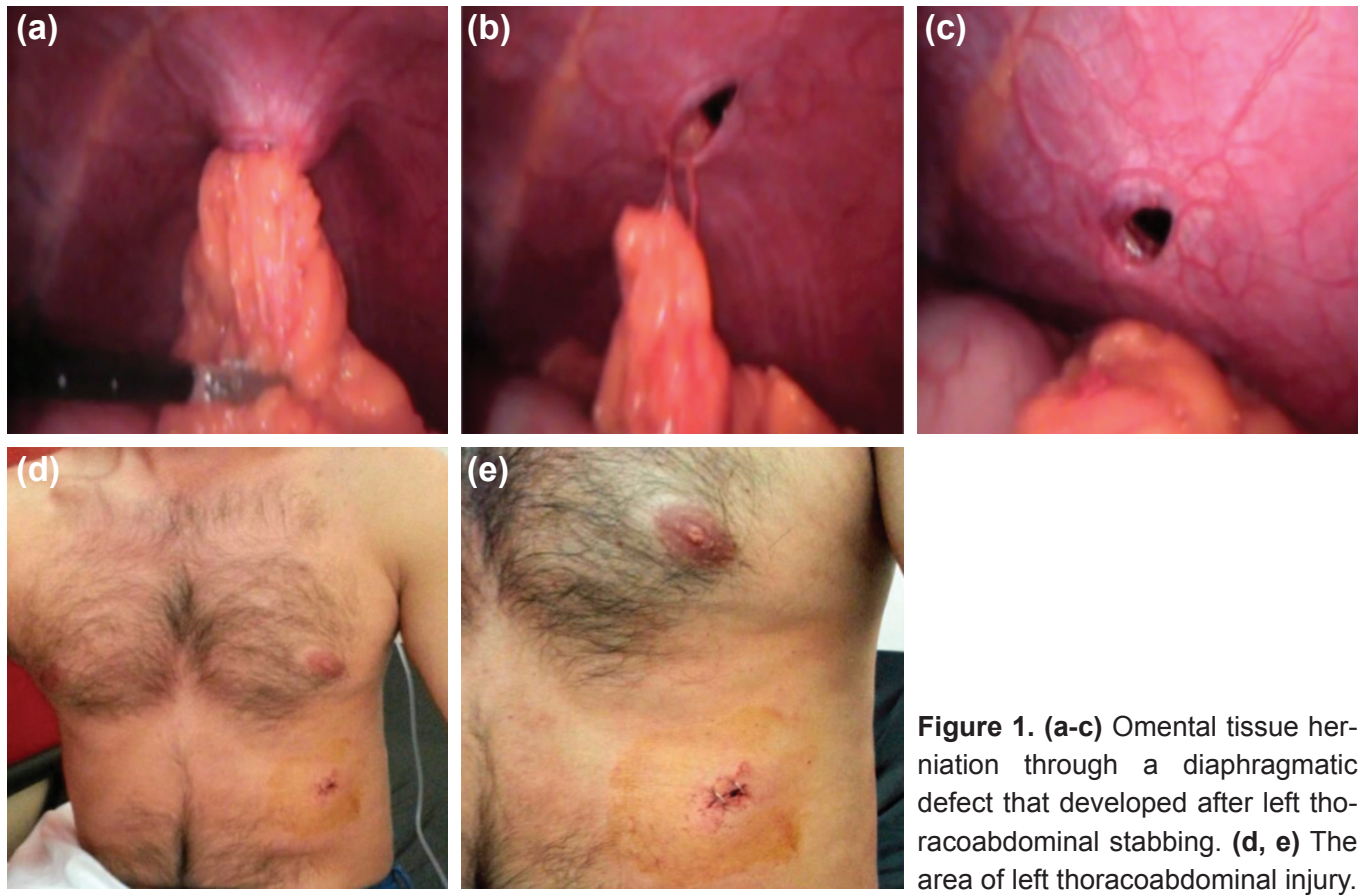

Figure 1. (a-c) Omental tissue herniation through a diaphragmatic defect that developed after left thoracoabdominal stabbing. (d, e) The area of left thoracoabdominal injury. 

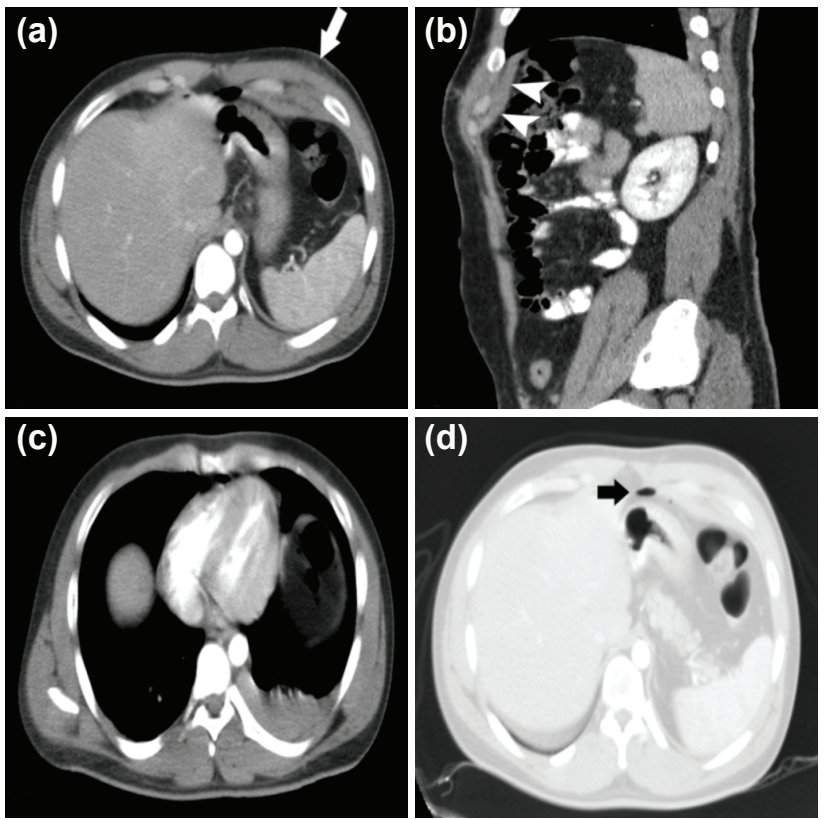

Figure 2. A 21-year-old man presented with left thoracoabdominal stabbing wound (a) Axial thoracoabdominal CT with contrast administration shows a stabbing tract with an oblique course (arrow) presented with hemorrhagic regions within intercostal muscle groups and thickened areas localized anterior to left diaphragm. (b) Sagittal multiplanar reformatted image clearly delineates the thickened section of diaphragm (arrowheads). (c) There also exists hemothorax in the basal part of left thorax. (d) Evaluation of the sections passing from upper abdomen via lung parenchymal window clearly demonstrates intraabdominal free air (black arrow). CT examination of this patient was labeled as false positive when laparoscopic examination revealed no diaphragmatic injury.

teen cases, of which 4 had grade I-II hepatic left lobe injury, I had grade III hepatic injury, 2 had grade III splenic injury, 3 had grade II splenic injury, I had grade IV splenic injury, 2 had grade I-II left kidney injury, and I had pancreas injury; six of them underwent thoracoscopy. A urinalysis was ordered in twentyseven cases with left posterior thoracic injury. Five patients had hematuria, of which one was macroscopic (grade-Il left kidney injury). A repeat urinalysis test 12 hours after the initial test was normal in the other four patients. These additional traumas increased the duration of hospital stay.

The dependent viscera sign was not observed in any patient. Eighteen patients had discontinuous diaphragma sign while dangling diaphragma sign was not observed in any patient. The diagnosis of diaphragmatic injury was confirmed by surgery in all cases with a MDCT clearly showing a diaphragmatic defect. A false positive result was obtained in four cases. Three out of them were with suspected diaphragmatic discontinuity and one had thickening of the diaphragm on CT. Focal thickening was present in eight cases, of which only three had confirmed diaphragmatic injury (Fig. 2). Six cases had intraabdominal fatty tissue herniation through a clearly visible diaphragmatic defect, although no case of solid or hollow organ herniation was seen. Only two cases had mesen-
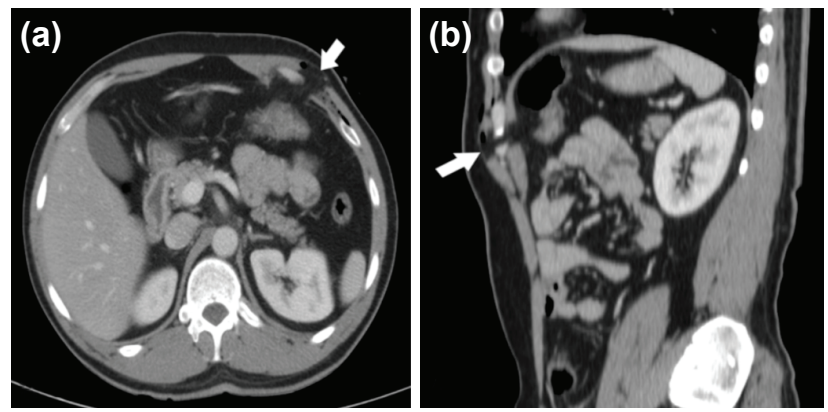

Figure 3. A 42-year-old man presented with left thoracoabdominal stabbing wound. (a) Axial thoracoabdominal CT examination with contrast administration shows full-thickness tear in anterior abdominal wall, intercostal muscle groups, and diaphragm as well as herniation of intraabdominal fatty tissue to subcutaneous tissue along the stabbing tract (arrow). (b) Sagittal multiplanar reformatted image shows diaphragmatic thickening and defect (arrow). Both images clearly show injury tract and surrounding subcutaneous air bubbles. This case was correctly diagnosed by CT prior to operation.
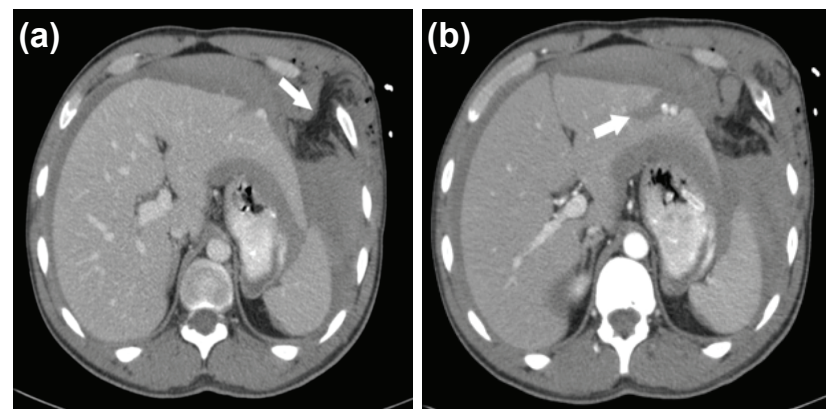

Figure 4. A 30-year-old man presented with left thoracoabdominal stabbing wound. (a) Axial thoracoabdominal CT examination with contrast administration shows subcutaneous air bubbles and hematoma formation in left-anterior abdominal wall as well as omental herniation through the large defect in diaphragm (arrow). (b) An arterial phase axial CT images passing more inferiorly demonstrates a large laceration and tiny pseudoaneurysm in left lobe of liver (arrow). In both images intraabdominal free fluid formations with a dense character consistent with diffuse hemoperitoneum are noted. The operative findings and CT signs were in agreement in this patient.

teric fatty tissue herniation and associated collar sign. All of the six cases with intraabdominal fatty tissue herniation had laparoscopically confirmed diaphragmatic defect (Figs. 3, 4). Twenty-four cases had contiguous injury, in 17 of which a diaphragmatic injury was confirmed. Considering all CT signs combined, CT had a sensitivity of $80 \%$ (95\% Cl: 59\%-93\%), a specifity of $95 \%$ (95\% Cl: $88 \%-99 \%)$, a PPV of $83 \%(95 \% \mathrm{Cl}$ : 63\%-95\%), NPV 94\% (95\% Cl: 87\%-98\%) (Table 2). The most common finding accompanying diaphragmatic injury was hemopneumothorax; whereas, the least common findings were retroperitoneal free air, and hematoma (Table 3).

\section{DISCUSSION}

Management of patients with minimal or asymptomatic left thoracoabdominal penetrating injuries is still a difficult task 
Table 2. The diagnostic efficacy of computed tomography for detection of diaphragmatic injury

\begin{tabular}{llccc}
\hline & & \multicolumn{2}{c}{ Diaphragmatic injury } & \\
\cline { 3 - 4 } & & Present & Absent & Total \\
\hline \multirow{2}{*}{ Computed tomography } & Positive & 20 & 4 & 24 \\
& Negative & 5 & 79 & 84 \\
& Total & 25 & 83 & 108 \\
\hline
\end{tabular}

Sensitivity: 80\% Specificity: \%95; PPV: 83\% NPV: 94\%

Table 3. Computed tomography findings accompanying diaphragmatic injury in penetrating thoracoabdominal trauma

\begin{tabular}{lcccc}
\hline Signs & \multicolumn{4}{c}{ Diaphragmatic injury } \\
\cline { 2 - 5 } & \multicolumn{2}{c}{ Positive $(\mathbf{n = 2 5 )}$} & Negative (n=83) \\
\cline { 2 - 5 } & $\mathbf{n}$ & $\%$ & $\mathbf{n}$ & $\%$ \\
\hline Subcutaneous emphysema & 6 & 24 & 33 & 40 \\
Subcutaneous haematoma & 7 & 28 & 18 & 21 \\
Pneumothorax & 6 & 24 & 45 & 54 \\
Haemothorax & 16 & 64 & 41 & 49 \\
Solid organ injury & $9 *$ & 36 & $5^{\#}$ & 1 \\
Mesenteric stranding & 8 & 32 & 9 & 1 \\
Intraperitoneal air & 6 & 24 & 8 & 1 \\
Intraperitoneal fluid & 13 & 52 & 14 & 2 \\
Retroperitoneal air & 1 & 4 & 2 & 0 \\
Retroperitoneal fluid & 2 & 8 & 4 & 0 \\
\hline
\end{tabular}

*Spleen: 5, liver: 4, "kidney: 2, spleen: I, liver: I, pancreas: I

for trauma surgeons working in emergency departments. Although there is no doubt that surgical intervention is needed in case of hemodynamic instability or peritoneal irritation, deciding whether diaphragmatic injuries are present is currently the main challenging task in penetrating thoracoabdominal injuries. A surgeon should promptly decide upon the need for surgery and the diagnostic procedure to be used in a patient with penetrating thoracoabdominal injury. The aim of diagnostic approach is to reduce the rate of unnecessary operations and not to miss the necessary ones. Studies have shown that physical examination can predict laparotomy need in an accurate and reliable manner. ${ }^{[5,6]}$ After application of the standard resuscitative approach as the initial approach in all patients, our diagnostic algorithm used leucocyte counting, serial physical examinations, and other tests to exclude additional intraabdominal pathologies. In this algorithm, the emergence of the signs of diffuse peritonitis was considered a reliable sign for the decision on laparotomy, as also suggested by other studies. ${ }^{[7,8]}$

Diagnostic laparoscopy is currently used not only for diagnos- tic purposes, but also for therapeutic purposes. ${ }^{[9-11]}$ Despite its limited role in anterior abdominal injuries, diagnostic laparoscopy is a suitable method for laparoscopic assessment and intervention in thoracoabdominal penetrating injuries. ${ }^{[12]} \mathrm{We}$ prefer performing diagnostic laparoscopy to detect diaphragmatic injuries in all patients with left thoracoabdominal injuries. In our study, twenty-three of the 95 patients undergoing diagnostic laparoscopy were diagnosed with diaphragmatic injury that were laparoscopically treated. One of the seven patients undergoing single-port diagnostic laparoscopy was detected with diaphragmatic injury that was primarily treated.

Thoracoscopy can be used for diagnostic and therapeutic purposes by experienced surgical teams in selected cases with penetrating trauma. ${ }^{[13]}$ One of the 6 patients undergoing diagnostic thoracoscopy was diagnosed with diaphragmatic injury that was laparoscopically treated.

Despite being regarded as the most valuable imaging modality for diagnosing diaphragmatic traumas, diagnostic role of CT is still flawed by some difficulties. The sensitivity and specificity 
of CT for the diagnosis of diaphragmatic rupture are $61 \%$ to $87 \%$ and $72 \%$ to $100 \%$, respectively. ${ }^{[3]}$ Previous studies have reported various $\mathrm{CT}$ signs facilitating the diagnosis of diaphragmatic injuries. Discontinuous diaphragm sign, thickening of the diaphragm, hypoattenuated diaphragm, dependent viscera sign, dangling diaphragm sign, collar sign, contiguous injury sign, sinus cut-off sign, and diaphragmatic/peridiaphragmatic contrast extravasation are the well-defined CT signs of blunt and penetrating traumas. ${ }^{[2,3,14]}$

Identification of these signs would provide valuable information in the diagnostic process. Most previous studies contained patient populations focused on blunt traumas or mixed series. However, the pathophysiolgies of blunt and penetrating traumas are markedly different, and radiological features may be different. ${ }^{[14]}$ It should be remembered that signs like collar sign, dependent viscera sign, and organ herniation are more common in larger defects and blunt traumas with concurrent intraabdominal pressure increase (in contrast to stab wounds). Among these signs, only the collar sign was observed in two cases in our study, which included only left-sided thoracoabdominal injuries. Six patients had intraabdominal fatty tissue herniation of variable amounts.

In trauma patients, diaphragmatic thickening may occur due to muscle edema or intramuscular hematoma. ${ }^{[2]}$ We observed that focal or diffuse diaphragmatic thickening had a low sensitivity and specificity for the detection of diaphragmatic injury. It has also previously been reported that this was a non-specific sign for penetrating traumas. ${ }^{[2]}$ This may be attributed to possible differences in diaphragmatic thickness in its different regions, as well as possible variability in its appearance in different subjects. ${ }^{[14]}$ In addition, it has been reported that this sign is specific for blunt traumas rather than penetrating traumas. ${ }^{[2,3]}$

A good agreement was found between CT signs and operative findings in all cases with a clearly visualized defect. A diaphragmatic injury extending to both sides of diaphragm was detected (contiguous injury sign) in seventeen patients with a diaphragmatic defect that was later repaired. In our series, diaphragmatic discontinuity and abdominal fatty tissue herniation were the most specific signs, and the contiguous injury sign was the most sensitive sign.

Although it was not the primary focus of our study, we suggest, based on our experiences, that evaluation of coronal and sagittal plane images would also be useful and increase the likelihood of diagnosis while evaluating diaphragmatic injuries. A retrospective study investigating the efficacy of MDCT in penetrating thoracic trauma reported a higher sensitivity and specifity than previous studies. The sensitivity of CT for exclusion of diaphragmatic injury was reported $94 \%$, which was attributed to imaging with high-resolution reformatted images. ${ }^{[15]}$ That study also reported that the most useful CT finding was "extension of injury tract to diaphragm". Bodana- pally et al. have reported that the contiguous injury sign is the most valuable sign (sensitivity, $88 \%$; specificity, $82 \%$ ) in single-entry wounds. ${ }^{[2]}$

Our study had some limitations. First, it had a retrospective design, which may be considered an important limitation. Second, no inter-observer variability analysis was done since all CT studies were done by the same radiologist.

\section{Conclusion}

Despite diagnostic challenges for the examination of penetrating diaphragmatic injuries with $\mathrm{CT}$, a thorough knowledge about the pathophysiology of penetrating traumas, familiarity with CT signs of these injuries, and three-dimensional reconstruction techniques may improve diagnostic accuracy. Our study showed a high specificity and relatively high sensitivity for MDCT in the detection of diaphragmatic injuries. Visualizing a diaphragmatic defect and fatty tissue herniation definitely makes the diagnosis of diaphragm injury. Presence of hemopneumothorax in conjunction with intraabdominal free air-fluid or intraabdominal organ injury supports the presence of a diaphragmatic injury even if a diaphragmatic defect is not clearly visualized. Diaphragmatic injuries in left thoracoabdominal sharp penetrating object injuries can be accurately diagnosed and repaired. However, our study was designed retrospectively in a specific patient population. More prospective studies with larger sample size are needed to better define the diagnostic efficacy of CT in left penetrating thoracoabdominal traumas.

\section{Conflict of interest: None declared.}

\section{REFERENCES}

1. Balaguera J, Garcia-Almata M, Segovia J, Aquiriano L, Delgado de Tórres S, Gamarra S, et al. Delayed asymptomatic left traumatic diaphragmatic hernia after abdominal stab wound. The Internet Journal of Surgery 2008;17:2.

2. Bodanapally UK, Shanmuganathan K, Mirvis SE, Sliker CW, Fleiter TR, Sarada K, et al. MDCT diagnosis of penetrating diaphragm injury. Eur Radiol 2009;19:1875-81. CrossRef

3. Panda A, Kumar A, Gamanagatti S, Patil A, Kumar S, Gupta A. Traumatic diaphragmatic injury: a review of CT signs and the difference between blunt and penetrating injury. Diagn Interv Radiol 2014;20:121-8.

4. American College of Surgeons. Advanced trauma life support, Chicago, 1997.

5. Clarke DL, Allorto NL, Thomson SR. An audit of failed non-operative management of abdominal stab wounds. Injury 2010;41:488-91. CrossRef

6. Kent AL, Jeans P, Ewards JR, Byrne PD. Ten year review of thoracic and abdominal penetrating trauma management. Aust N Z J Surg 1993;63:772-9. CrossRef

7. Navsaria PH, Berli JU, Edu S, Nicol AJ. Non-operative management of abdominal stab wounds--an analysis of 186 patients. S Afr J Surg 2007;45:128-32.

8. Biffl WL, Kaups KL, Cothren CC, Brasel KJ, Dicker RA, Bullard MK, et al. Management of patients with anterior abdominal stab wounds: a Western Trauma Association multicenter trial. J Trauma 2009;66:1294- 
301. CrossRef

9. O'Malley E, Boyle E, O'Callaghan A, Coffey JC, Walsh SR. Role of laparoscopy in penetrating abdominal trauma: a systematic review. World J Surg 2013;37:113-22. CrossRef

10. Lin HF, Wu JM, Tu CC, Chen HA, Shih HC. Value of diagnostic and therapeutic laparoscopy for abdominal stab wounds. World J Surg 2010;34:1653-62. CrossRef

11. Sugrue M, Balogh Z, Lynch J, Bardsley J, Sisson G, Weigelt J. Guidelines for the management of haemodynamically stable patients with stab wounds to the anterior abdomen. ANZ J Surg 2007;77:614-20. CrossRef

12. Friese RS, Coln CE, Gentilello LM. Laparoscopy is sufficient to exclude occult diaphragm injury after penetrating abdominal trauma. J Trauma
2005;58:789-92. CrossRef

13. Bagheri R, Tavassoli A, Sadrizadeh A, Mashhadi MR, Shahri F, Shojaeian $\mathrm{R}$. The role of thoracoscopy for the diagnosis of hidden diaphragmatic injuries in penetrating thoracoabdominal trauma. Interact Cardiovasc Thorac Surg 2009;9:195-8, CrossRef

14. Hammer MM, Flagg E, Mellnick VM, Cummings KW, Bhalla S, Raptis CA. Computed tomography of blunt and penetrating diaphragmatic injury: sensitivity and inter-observer agreement of CT Signs. Emerg Radiol 2014;21:143-9. CrossRef

15. Stein DM, York GB, Boswell S, Shanmuganathan K, Haan JM, Scalea TM. Accuracy of computed tomography (CT) scan in the detection of penetrating diaphragm injury. J Trauma 2007;63:538-43. CrossRef

\section{ORIJINAL ÇALIŞMA - ÖZET}

\section{Torakoabdominal delici-kesici alet yaralanmalarında bilgisayarlı tomografinin diyafragma yaralanmasını göstermedeki etkinliği, tanısal laparoskopi ile karşılaştırma}

\section{Dr. Mehmet İlhan, ${ }^{1}$ Dr. Mesut Bulakçı, ${ }^{2}$ Dr. Süleyman Bademler, ${ }^{1}$ Dr. Ali Fuat Kaan Gök, ${ }^{1}$}

\section{Dr. İbrahim Fethi Azamat, ${ }^{1}$ Dr. Cemalettin Ertekin ${ }^{1}$}

${ }^{1}$ İstanbul Üniversitesi İstanbul Tıp Fakültesi, Genel Cerrahi Anabilim Dalı, Travma ve Acil Cerrahi Servisi, İstanbul, Türkiye

${ }^{2}$ İstanbul Üniversitesi İstanbul Tıp Fakültesi, Radyoloji Anabilim Dalı, İstanbul

AMAÇ: Sol torakoabdominal delici kesici yaralanması olan, tanısal veya terapotik laparoskopi yapılan hastalarda bilgisayarlı tomografinin (BT) diyafram yaralanmasını saptamadaki etkinliğinin değerlendirilmesi.

GEREÇ VE YÖNTEM: Nisan 2010 ile aralık 2014 tarihleri arasında delici-kesici alet yaralanması ile başvuran sol torakoabdominal yaralanması bulunan 108 olgu demografik verileri, bıçaklanma bölgesi, ek travma bulgularının varlığı, hemodinamik parametreleri, başvuru süresi, tanı yöntemleri ve tedavi şekli açısından geriye dönük olarak değerlendirildi. Tüm hastaların ameliyat öncesi bilgisayarlı tomografi görüntüleri geriye dönük olarak cerrahi değerlendirme sonuçları bilinmeden değerlendirilmiştir. Hemotoraks, pnömotoraks, batında serbest sıvı ve solid organ yaralanmalarının diyaframa yaralanması ile ilişkisi araştırıldı. Cerrahi girişim öncesinde tüm olgular fizik muayene, hemogram takibi ve hemodinamik değerlendirme ile takip edildi.

BULGULAR: Fizik muayene bulgusu olarak en sık anterior sol torakoabdominal yaralanma saptandı. Lateral yaralanması olan 25 olgunun \%36'sında cerrahi olarak yaralanma saptandı. Tüm olguların 25'inde (\%23. I) diyafragma yaralanması saptandı ve olgulara laparaskopik tamir yapıldı. Tüm BT bulguları cerrahi sonuçları ile birlikte değerlendirildiğinde diyafragma yaralanmasını göstermede sensitivite \%80, spesifite \%95, PPV \%83, NPV \%94 olarak hesaplanmıştır. Ortalama hastanede kalış süresi tüm olgularda 5.4 gün (I-I6) olarak gözlendi.

TARTIŞMA: Bilgisayarlı tomografi ile penetran diyafragma yaralanmalarını değerlendirmede halen güçlükler mevcuttur. Buna rağmen bizim çalışmamızda BT yüksek spesifite ve negatif prediktif değere sahiptir. Diyafragma defekti ve yağlı doku herniasyonunun tespit edilmesi torakoabdominal yaralanmalarda kesin tanıyı koydurmaktadır. Daha fazla sayıda hasta grubu ile ileriye yönelik çalışma yapılması, delici kesici alete bağlı torakoabdominal yaralanması olan hastalarda diyafram yaralanmasının saptanmasında BT'nin rolünü belirlemede faydalı olacaktır.

Anahtar sözcükler: ÇKBT; delici kesici alet yaralanması; diyafragma yaralanması; laparoskopi; torakoabdominal.

Ulus Travma Acil Cerrahi Derg 20I5;2I(6):484-490 doi: 10.5505/tjtes.2015.94389 